\title{
A clinical and echocardiographic study of patients with the hypermobility syndrome
}

\author{
R. GRAHAME, J. C. EDWARDS, D. PITCHER, A. GABELL, AND W. HARVEY \\ From Guy's Arthritis Research Unit and the Department of Cardiology, Guy's Hospital Medical School, \\ London SE1 9RT
}

SUMMARY Three age- and symptom-matched groups of patients with a hypermobility score of $5-9,3-4$, and $0-2$ (controls), respectively, were examined for clinical and echocardiographic evidence of mitral valve prolapse and other stigmata of a collagen disorder. Mitral valve prolapse, a reduced upper segment/lower segment mitral ratio, reduced skin thickness, spinal anomalies, and a history of fracture were found to be significantly commoner among the hypermobile patients than the controls. The data suggest that the so-called hypermobility syndrome, far from being a benign locomotor disorder of healthy persons, may be a forme fruste of a hereditary disorder of connective tissue.

Generalised joint hypermobility resulting from ligamentous laxity is a feature of many hereditary disorders of connective tissue, such as the Marfan syndrome, osteogenesis imperfecta, and Ehlers-Danlos syndrome. ${ }^{1}$ The term 'hypermobility syndrome' was coined by Kirk et al. ${ }^{2}$ to denote the presence of rheumatic symptoms in otherwise healthy subjects in whom generalised joint laxity is the only observed abnormality. Subsequent studies have confirmed both the association between articular and spinal complaints and hypermobility ${ }^{3} 4$ and the hereditary nature of the ligamentous laxity, which may be inherited by both dominant and recessive modes of inheritance. ${ }^{56}$

Up to the present time the "hypermobility syndrome' has been considered to be a benign disorder giving rise to certain articular complications such as predisposition to ligament rupture, ${ }^{7}$ dislocations, ${ }^{8}$ recurrent effusions, ${ }^{9}$ Baker's cyst formation, ${ }^{10}$ low back pain, ${ }^{4}$ spondylolisthesis (H. Bird, personal communication), and possibly premature osteoarthrosis, ${ }^{11}$ but not associated with disorders in other systems. In particular, evidence that it might be part of a generalised connective tissue disorder has not been forthcoming. This study sets out to explore that hypothesis.

\section{Patients and methods}

Eighty-seven patients ( 80 female and 7 male) attending

Accepted for publication 16 December 1980

Correspondence to Dr R. Grahame, Guy's Arthritis

Research Unit, Guy's Hospital Medical School, London Bridge, London SE1 9RT. the rheumatology clinic at Guy's Hospital with rheumatic complaints were selected and agreed to take part. Patients were excluded from the study if they showed evidence of inflammatory joint disease or if they had typical features of one of the identifiable hereditary disorders of connective tissues. Two patients with Ehlers-Danlos syndrome type I were excluded under this category. It was not possible to differentiate between the hypermobility syndrome under investigation and Ehlers-Danlos syndrome type III, in which joint hypermobility is generalised and gross while skin hyperextensibility and scarring may be minimal..$^{12}$ Patients were allocated to 1 of 3 groups matched in terms of age and presenting locomotor symptom according to their hypermobility score (HMS) on well established criteria $^{12}$ which gave a maximum score of 9 points (Table 1). Since only 7 males presented for the study, it was decided to exclude their data from the analysis. Group A comprised those female patients scoring $5-9$, group B those scoring 3-4, while group C, containing female patients with a score of $0-2$, acted

Table 1 Hypermobility scoring system (after Beighton and Horan $^{12}$ )

Passive hyperextension of the 5th metacarpophalangeal joint to $90^{\circ}$ scores 1 for each hand

Passive apposition of the thumb to the volar aspect of the forearm scores 1 for each arm

Passive hyperextension of the elbow to more than $10^{\circ}$ scores 1 for each arm

Passive hyperextension of the knees to beyond $10^{\circ}$ scores 1 for each leg Placing hands flat on floor by flexing spine while maintaining knees straight scores 1

Maximum score 9 
as controls. There were 33 patients in group A, 21 in group B, and 26 in group C. All subjects were Caucasian with the exception of 3 in group $A, 2$ in group B, and 1 in group C.

All patients attended for a detailed clinical evaluation. Information was sought concerning past and present rheumatological and orthopaedic complaints. Measurements of height, arm span, and upper segment/lower segment (US/LS) ratio were recorded. Skinfold thickness was measured on the dorsum of the right hand overlying the third metacarpal with the Harpenden caliper. ${ }^{13}$ In-vivo skin elasticity was also measured by the suction cup method. ${ }^{14}$ Where available, spinal radiographs were examined, and the frequency of observed abnormalities was compared in the 3 groups of patients.

A full cardiological examination, including electrocardiography and echocardiography, was performed by a 'blind' independent observer. Auscultation of the heart was performed with the patient in the supine, left lateral, and standing positions. M-mode echocardiograms were recorded with an Ekoline 20A ultrasonoscope equipped with a $2.25 \mathrm{MHz}$ transducer focused at $10 \mathrm{~cm}$ and an Ekoline 21 strip-chart recorder (Smith Kline Instruments). During the recording particular attention was paid to the presence or absence of echocardiographic evidence of mitral valve prolapse (MVP). The echocardiograms were analysed on a subsequent occasion under 'blind' conditions. Abrupt posterior motion of the mitral echo in midsystole or pansystolic posterior bowing of the mitral echo of at least $3 \mathrm{~mm}$ in depth were taken as evidence of MVP (Fig. 1). This was classified as mild when the depth of prolapse was $4 \mathrm{~mm}$ or less and marked when the depth of prolapse exceeded $4 \mathrm{~mm}$.

Statistical significances were determined by the chi-square method, with the exception of the skin studies, where Student's $t$ test was used.

\section{Results}

The 3 groups were well matched in respect of age and presenting symptom (Table 2). Low back pain was slightly more prevalent and joint problems less frequent in the control group, but these differences did not achieve statistical significance.

\section{ASSOCIATED SYMPTOMS}

Other symptoms of a rheumatological nature or suggestive of a connective tissue disorder are shown in Table 3. Some of these-effusions, muscle cramps, easy bruising, and varicose veins-were common in all 3 groups and appeared with approximately

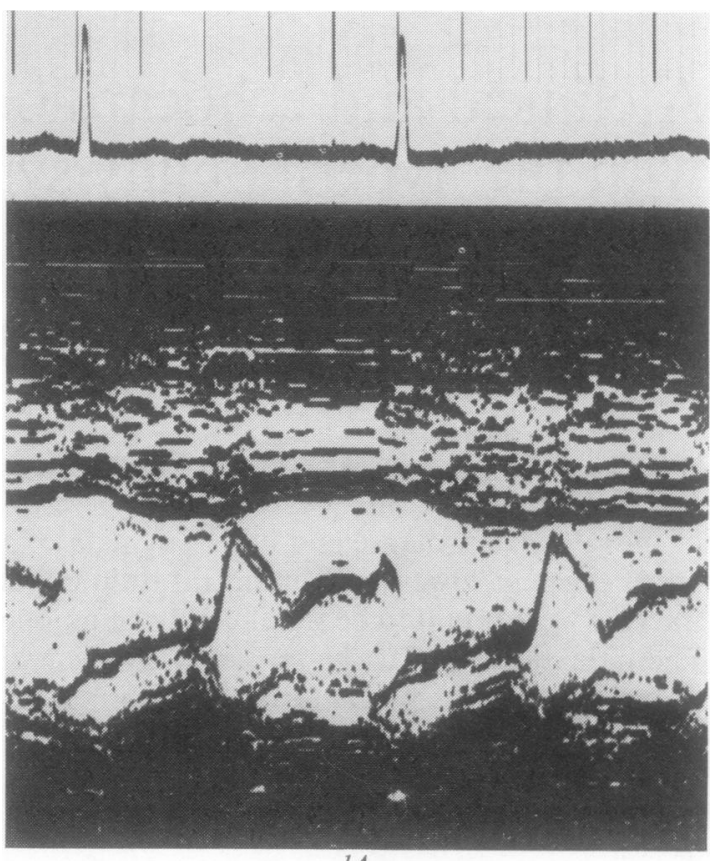

$1 A$
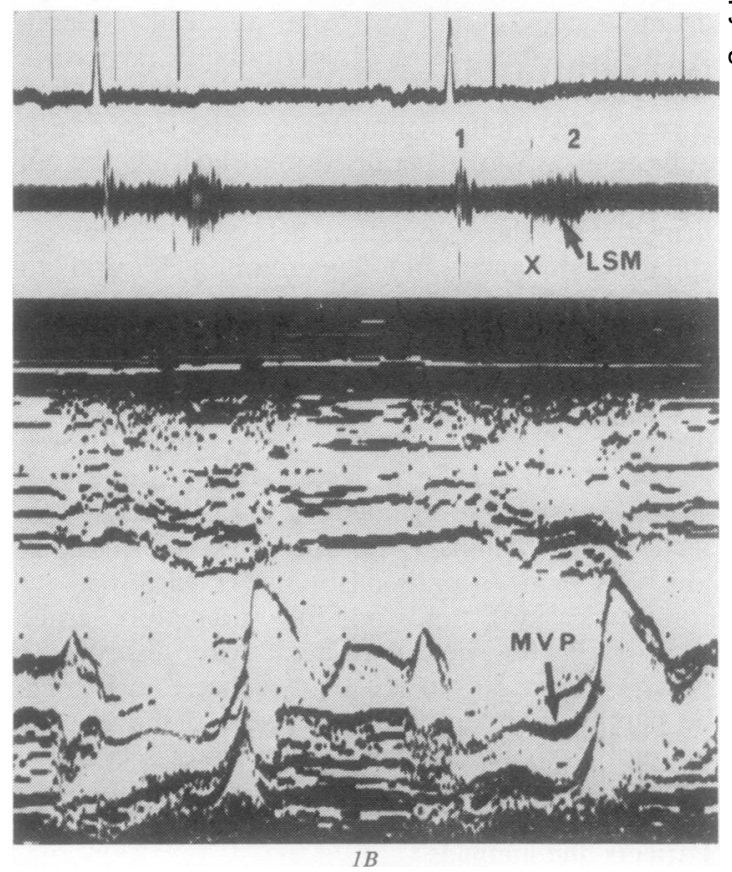

Fig. 1 A, a normal mitral echogram and, $B$ an echocardiogram from one of our hypermobile patients with $M V P$, seen as abrupt posterior movement of the mitral echo in mid systole. The mid systolic click $(x)$ and late systolic murmur (LSM) are shown on the simultaneous phonocardiogram. 
Table 2 Patient characteristics and presenting symptoms

\begin{tabular}{|c|c|c|c|c|c|c|}
\hline Group: & $A$ & & $B$ & & $C(\mathrm{Cor}$ & ontrols) \\
\hline Hypermobility score: & $H M S$ & $5-9$ & $H M S$ & $3-4$ & $H M S$ & $0-2$ \\
\hline $\begin{array}{l}\text { Number } \\
\text { Mean age (range) }\end{array}$ & & $\begin{array}{l}33 \\
38 \\
(19-64)\end{array}$ & & $\begin{array}{l}21 \\
38 \\
(22-61)\end{array}$ & & $\begin{array}{l}26 \\
46 \\
(23-70)\end{array}$ \\
\hline $\begin{array}{l}\text { Back pain } \\
\text { Joint problems }\end{array}$ & & $73 \%$ & & $76 \%$ & & $81 \%$ \\
\hline $\begin{array}{l}\text { Osteoarthritis } \\
\text { Arthralgia }\end{array}$ & $\begin{array}{l}24 \% \\
58 \%\end{array}$ & & $\begin{array}{l}19 \% \\
67 \%\end{array}$ & & $\begin{array}{l}23 \% \\
42 \%\end{array}$ & \\
\hline Total & & $82 \%$ & & $86 \%$ & & $65 \%$ \\
\hline
\end{tabular}

Table 3 Clinical features

\begin{tabular}{lccc}
\hline $\begin{array}{l}\text { Incidence of } \\
\text { history of }\end{array}$ & $\begin{array}{l}\text { Group A } \\
\text { HMS 5-9 }\end{array}$ & $\begin{array}{l}\text { Group B } \\
\text { HMS 3-4 }\end{array}$ & $\begin{array}{l}\text { Group C } \\
\text { controls } \\
\text { HMS 0-2 }\end{array}$ \\
\hline Fracture & $17 / 33(52 \%)^{* *}$ & $3 / 21(14 \%)$ & $4 / 26(15 \%)$ \\
Dislocation & $5 / 33(15 \%)$ & $1 / 21(5 \%)$ & $1 / 26(4 \%)$ \\
Raynaud's & $7 / 33(21 \%)$ & $2 / 21(10 \%)$ & $2 / 26(8 \%)$ \\
phenomenon & $5 / 33(15 \%)$ & $1 / 21(5 \%)$ & $1 / 26(4 \%)$ \\
Capsulitis & $10 / 33(30 \%)$ & $4 / 21(19 \%)$ & $10 / 26(38 \%)$ \\
Effusions & $17 / 33(52 \%)$ & $11 / 21(52 \%)$ & $8 / 26(31 \%)$ \\
Muscle cramps & $3 / 33(9 \%)$ & $1 / 21(5 \%)$ & $2 / 26(8 \%)$ \\
Calf swelling & $16 / 33(48 \%)$ & $10 / 21(48 \%)^{*}$ & $6 / 26(23 \%)$ \\
Ligament injuries & $5 / 33(15 \%)$ & $1 / 21(5 \%)$ & $4 / 26(15 \%)$ \\
Epicondylitis & & $1 / 21$ & $2 / 26$ \\
Carpal tunnel & $2 / 33$ & 0 & $1 / 26$ \\
syndrome & $4 / 33$ & $2 / 21$ & $2 / 26$ \\
Muscle tear & $2 / 33(73 \%)$ & $14 / 21(67 \%)$ & $16 / 26(62 \%)$ \\
Poor skin healing & $24 / 33(73 \%)$ & $6 / 26(23 \%)$ \\
Bruising & $5 / 33(15 \%)$ & $6 / 21(29 \%)$ & $6 / 26)$ \\
Varicose veins & &
\end{tabular}

Compared with controls: **p $<0.01,{ }^{*} p<0.05$.

equal frequency in all of them. Others-a history of dislocation, Raynaud's phenomenon, shoulder capsulitis, and muscle tears-were more frequent in the hypermobile groups than in the controls, but the differences were not significant. A history of previous fracture was found in $52 \%$ of patients in group A compared with only $15 \%$ in the controlsa highly significant difference $(p<0 \cdot 01)$. A significant increase in the incidence of ligament injuries was seen in both hypermobile groups $\mathbf{A}$ and $\mathbf{B}$ as compared with controls $(p<0.05)$.

\section{SPINAL X-RAYS}

Spinal anomalies including scoliosis, transitional vertebrae at the lumbosacral junction, and pars interarticularis defects with or without spondylolisthesis were present in $11(73 \%)$ out of 15 patients $x$-rayed in group A, in $3(33 \%)$ out of $9 x$-rayed in group B, and in only $3(23 \%)$ out of $13 x$-rayed in group C. Differences between group $A$ and the controls were significant $(p<0.01)$ (Table 4). None of the controls had a spondylolisthesis or a pars defect.
Table 4 Spinal anomalies

\begin{tabular}{lcccccc}
\hline Group & \multicolumn{2}{c}{ X-rayed } & & \multicolumn{2}{c}{$\begin{array}{l}\text { Those } x \text {-rayed and } \\
\text { having anomalies }\end{array}$} \\
\cline { 2 - 3 } \cline { 5 - 6 } \cline { 5 - 6 } & No. & $\%$ & & No. & $\%$ \\
\hline Group A (HMS 5-9) & $15 / 33$ & $45 \%$ & & $11 / 15$ & $73 \%^{*}$ \\
Group B (HMS 3-4) & $9 / 21$ & $43 \%$ & & $3 / 9$ & $33 \%$ \\
Group C controls (HMS 0-2) & $13 / 26$ & $50 \%$ & & $3 / 13$ & $23 \%$ \\
\hline
\end{tabular}

$* \mathrm{p}<0.01$.

CARDIOLOGICAL FINDINGS (Table 5)

The systolic click of mitral valve prolapse (MVP) was heard in $18 \%$ of patients in group $\mathrm{A}, 17 \%$ in group B, and in only 1 case (6\%) in group C. A mitral regurgitant murmur was heard in $9 \%$ and $17 \%$ in groups $A$ and $B$ respectively and in no case in group $\mathrm{C}$.

Echocardiographic findings in the 3 groups are detailed in Fig. 2 and Table 5. Both hypermobile groups (A and B) showed a significantly greater prevalence of MVP than the control group, C. Measurements of left atrial depth and aortic root diameter from the echocardiograms were not significantly different in any of the 3 groups. Left atrial depth exceeded the normal range in 2 patients from each group. There was a trend towards a positive correlation between anterior mitral leaflet excursion (MVE) and hypermobility score but this did not reach statistical significance $(r=0 \cdot 23$, $\mathrm{p}>0.05$ ).

Abnormal resting electrocardiograms were recorded in 7 patients, 5 of whom had MVP. In group A 5 patients had abnormal ECGs compared with only 1

GROUPING OF SUBJECTS WITH MITRAL VALVE PROLAPSE

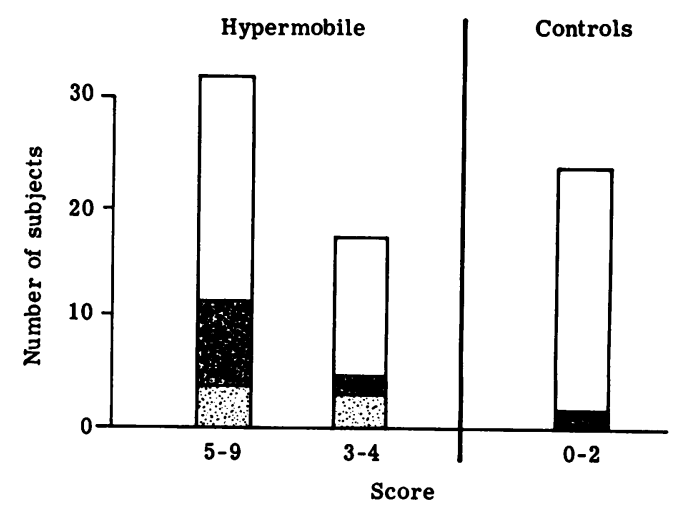

no MVP detected mild MVP marked MVP

Fig. 2 The incidence of mild (hatched) and marked (stippled) MVP in the different hypermobility groups. 
Table 5 Cardiological findings

\begin{tabular}{|c|c|c|c|}
\hline & Patients & & Controls \\
\hline Hypermobility score & $5-9$ & $3-4$ & $0-2$ \\
\hline Click & $6 / 33(18 \%)$ & $3 / 18(17 \%)$ & $1 / 25(4 \%)$ \\
\hline Murmur & $3 / 33(9 \%)$ & $3 / 18(17 \%)$ & $0 / 25$ \\
\hline \multicolumn{4}{|l|}{ Echocardiographic evidence of MVP } \\
\hline Marked & $4 / 33(12 \%)$ & $3 / 18(17 \%)$ & $0 / 25$ \\
\hline Mild & $8 / 33(24 \%)$ & $2 / 18(11 \%)$ & $2 / 25(8 \%)$ \\
\hline Total & $12 / 33 * *(36 \%)$ & $5 / 18(28 \%)^{* *}$ & $2 / 25(8 \%)$ \\
\hline $\begin{array}{l}\text { Mean left atrial depth } \mathrm{cm} \pm \mathrm{SD} \\
\text { (normal range } 1.9-3.8 \mathrm{~cm} \text { ) }\end{array}$ & $3 \cdot 0 \pm 0 \cdot 5$ & $3.0 \pm 0.6$ & $3 \cdot 1 \pm 0 \cdot 5$ \\
\hline $\begin{array}{l}\text { Mean mitral valve excursion, } \mathrm{cm} \pm \mathrm{SD} \\
\text { (normal range } 1 \cdot 8-2 \cdot 5 \text { ) }\end{array}$ & $2 \cdot 1 \pm 0 \cdot 3$ & $2 \cdot 0 \pm 0 \cdot 3$ & $1 \cdot 9 \pm 0 \cdot 3$ \\
\hline Aortic diameter $\mathrm{cm} \pm \mathrm{SD}$ (normal range $2 \cdot 0-3 \cdot 7$ ) & $2 \cdot 8 \pm 0.4$ & $2 \cdot 7 \pm 0 \cdot 3$ & $2 \cdot 8 \pm 0.3$ \\
\hline Electrocardiographic abnormalities-RBBB & & 01 & \\
\hline 1st Degree heart block & 1 & 0 & 0 \\
\hline Inferolateral ST sagging & 1 & $1 \dagger$ & 0 \\
\hline Frequent ventricular ectopic beats & 1 & $1 \dagger$ & 1 \\
\hline Abnormal QRS axis $\left(-30^{\circ}\right)$ & & & \\
\hline Total abnormal ECG & $5 / 29 *(17 \%)$ & $1 / 18(6 \%)$ & $1 / 16(6 \%)$ \\
\hline
\end{tabular}

${ }^{* *} \mathrm{p}<0.02,{ }^{*} \mathrm{p}<0.05$. † Same patient. RBBB $=$ right bundle branch block.

patient in each of the other groups. Details of the ECG abnormalities are summarised in Table 5.

\section{BODY HABITUS}

The numbers of patients showing a US/LS ratio of less than 0.89 in the 3 groups are shown in the histogram (Fig. 3). With groups A and B taken together the incidence of low US/LS ratio was 21 out of $54(39 \%)$ compared with 3 out of $26(11.5 \%)$ in the control group $\mathrm{C}(\mathrm{p}<0.05)$.

\section{SKIN ST UDIES}

For the skin thickness and elasticity studies patients were carefully selected to achieve the closest possible

\section{LOW UPPER SEGMENT/LOWER SEGMENT RATIO $(<0.89)$}

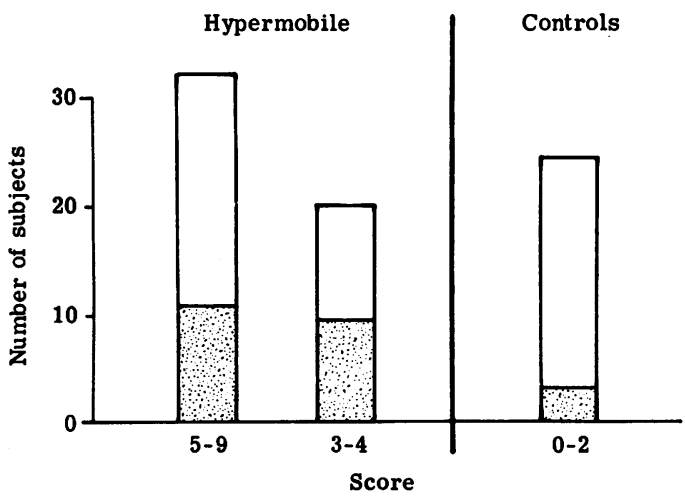

Fig. 3 The incidence of reduced US/LS ratio (less than 0.89 ) in the different hypermobility groups.
Table 6 Skin thickness and skin elasticity

\begin{tabular}{lccc}
\hline HMS patients & & $\begin{array}{l}\text { Matched } \\
\text { controls }\end{array}$ \\
\hline HM score & $5-9$ & $3-4$ & $0-2$ \\
Number & 16 & 16 & 16 \\
Skin thickness in cm & $0.098^{*}$ & 0.102 & 0.11 \\
( \pm SEM) & $( \pm 0.0026)$ & $( \pm 0.0027)$ & $( \pm 0.002)$ \\
Skin elasticity & 1.94 & 2.25 & 2.04 \\
PA $\times 10^{-7}( \pm$ SEM) & $( \pm 0.26)$ & $( \pm 0.27)$ & $( \pm 0.24)$ \\
\hline
\end{tabular}

$* \mathrm{p}<0.02$.

matching of the 3 groups in respect of age and presenting symptoms. In this way it was possible to select 3 matched groups each containing 16 patients. Results are given in Table 6 . It will be seen that with regard to skin thickness there was a trend towards an inverse relationship between hypermobility scores and skin thickness; the difference between group A (HMS 5-9) and the control group (HMS 0-2) achieved statistical significance $(\mathrm{p}<0.02)$. In contrast, there were no appreciable differences in skin elasticity between the 3 groups.

\section{CORRELATION BETWEEN OBSERVED}

\section{ABNORMALITIES}

Both arthralgia and a history of fracture were more frequent among patients with MVP in hypermobile groups A and B than in those without MVP in the same group, the difference being significant $(p<0.05)$ in respect of group A only. Thus arthralgia was seen in $83 \%$ of those patients in group A with MVP and in only $43 \%$ of those without it. In group B the corresponding figures were 80 and $69 \%$ respectively. For fractures the incidences in group A were $75 \%$ and $38 \%$ with and without MVP respectively. Corresponding figures for group B were $20 \%$ and 0 . 
Soft tissue lesions including epicondylitis, carpal tunnel syndrome, and tenosynovitis were more common in both hypermobile groups in patients with MVP than in those without it. The numbers, however, were small, and statistically significant trends were not seen. Lower US/LS ratios did not correlate with MVP in the hypermobile patients in either group. Unlike arthralgia, low back pain showed no association with MVP among the hypermobile patients.

Skin thickness correlated inversely with hypermobility score and also with age but not with US/LS ratio.

\section{Discussion}

Systolic prolapse of the mitral valve is a recently recognised entity. ${ }^{15} 16$ Its clinical hallmark is a nonejection systolic click, with or without a late systolic murmur, but in some patients it is clinically 'silent' and in others a pansystolic murmur may be present without a click. In clinical and echocardiographic studies MVP has been observed in $6.3 \%$ of 1169 healthy young females (17), and Brown et al. (18) found it is less frequent in males $(0.5 \%)$ than in females $(6 \%)$. The cause is believed to lie in defective or deficient collagen in the mitral leaflets ${ }^{19}$ leading to leaflet expansion and chordal elongation. MVP has been described in patients suffering from various hereditary disorders of connective tissue such as the Marfan syndrome, 2021 the Ehlers-Danlos syndrome, ${ }^{22}{ }_{23}$ and osteogenesis imperfecta, ${ }^{24}$ but not as yet in the hypermobility syndrome, ${ }^{2}$ which has hitherto been regarded as a benign disorder of the locomotor system affecting doublejointed but otherwise healthy persons.

A reduced skin thickness in the presence of a normal elastic modulus has been recorded in studies involving age- and sex-matched controls in both the Ehlers-Danlos syndrome ${ }^{25}$ and osteogenesis imperfecta. ${ }^{26}$ To the best of our knowledge no previous studies have been undertaken in patients with the hypermobility syndrome. Although increased extensibility of collagenous tissues is considered to be a cause of abnormalities such as joint laxity, kyphoscoliosis, floppy heart valves, and stretchy skin, ${ }^{27}$ our measurements of skin elasticity in these patients revealed no abnormality. Fragility of the collagen framework, however, could well account for the skeletal and cardiac abnormalities we have found. Fragility could reflect a quantitative decrease in collagen content of the tissues-as suggested by the reduced skin thickness-or a qualitative difference in the connective tissue architecture. This in turn could reflect a molecular defect in collagen, as is suggested by the recent observation of an increase in procollagen in floppy mitral valves. ${ }^{28}$

In the present study rheumatic patients with soft tissue or degenerative lesions were selected on the basis of their hypermobility score into 1 of 3 groups closely matched for age and presenting complaint. Since only 7 males $(9 \%)$ of those with an HMS presented themselves during the period of study (an observation in itself not without interest, particularly in relation to the reported sex distribution of MVP), it was decided to exclude them from the analysis. Also excluded were patients with an inflammatory joint disease and those considered to be suffering from one of the identifiable hereditary disorders of connective tissue. Two patients with the Ehlers-Danlos syndrome were excluded under this category. The remainder constituted 3 age- and symptom-matched groups; 2 (groups A and B with an HMS of 5-9 and 3-4 respectively) were diagnosed as suffering from the hypermobility syndrome and a third, group C, with an HMS of 0-2 acting as a control group.

The results show the increased prevalence of MVP, a reduced US/LS ratio, a reduced skin thickness, spinal anomalies, and a history of fracture among hypermobile subjects. These findings suggest that patients may have a collagen defect that is manifested not only in joint laxity but also in abnormalities in heart valves, skin, and bone. Furthermore, there appears to be an association with a marfanoid habitus as shown by the reduced US/LS ratio. The apparent occurrence of a generalised connective tissue defect in patients with the 'hypermobility syndrome' highlights the difficulty of differentiating between these patients and those with the milder forms of the Ehlers-Danlos syndrome. Indeed, we conclude that the so-called hypermobility syndrome may be a forme fruste of a hereditary disorder of connective tissue.

\section{References}

1 Grahame R. Hereditable Disorders. In: Scott J T, ed. Copeman's Textbook of the Rheumatic Diseases. Edinburgh, London, and New York: Churchill-Livingstone, 1978: 835-7.

2 Kirk J A, Ansell B M, Bywaters E G L. The hypermobility syndrome. Ann Rheum Dis 1967; 26: 419-25.

3 Beighton P, Solomon L, Soskolne C L. Articular mobility in an African population. Ann Rheum Dis 1973; 32: 413-8.

4 Howes R G, Isdale I C. The loose back, an unrecognised syndrome. Rheumatol Rehabil 1971; 11: 72-7.

5 Beighton P, Horan F. Dominant inheritance in generalised articular hypermobility. J Bone Joint Surg 1970; 52B: 145-7.

6 Horan F, Beighton P. Recessive inheritance of generalised joint hypermobility. Rheumatol Rehabil 1973; 12: 47-9. 
7 Nicholas J A. Injuries to the knee ligaments. Relationship to looseness and tightness in football players. $J A M A$ 1970; 212: 2236-9.

8 Carter C B, Sweetman R. Recurrent dislocation of the patella and of the shoulder: their association with familial joint laxity. J Bone Joint Surg 1960; 42B: 721-7.

9 Sutro C J. Hypermobility of the knees due to overlengthened capsular and ligamentous tissues. Surgery 1947; 21 : 67-76.

10 Grahame R. Hypermobility-clinical aspects. Proc $R$ Soc Med 1971; 64: 32-4.

11 Scott D, Bird H, Wright V. Joint laxity leading to osteoarthrosis. Rheumatol Rehabil 1979; 18: 167-9.

12 Beighton P, Horan S. Orthopaedic aspects of the Ehlers-Danlos syndrome. J Bone Joint Surg 1969; 51B: 444-53.

13. Tanner J M, Whitehouse H H. The Harpenden skinfold caliper. Am J Phys Anthropol 1955; 13: 743-6.

14 Grahame R. A method for measuring human skin elasticity in vivo with observations on the effects of age, sex and pregnancy. Clin Sci 1970; 39: 223-36.

15 Barlow J B, Bosman C K, Pocock W A, Marchant P, Denny $M$. The significance of late systolic murmurs. Am Heart $J$ 1963; 60: 443-52.

16 Hancock D W, Cohn K. The syndrome associated with mid-systolic click and late systolic murmur. Am J Med 1966; 41: 183-96.

17 Procacci P M, Savran V, Schreiter S L, Bryson A L. Prevalence of mitral valve prolapse in 1169 young women. N Engl J Med 1976; 294: 1086-8.

18 Brown O R, Kloster F E, De Mots H. Incidence of mitral valve prolapse in the asymptomatic normal. Circulation 1975; 52: suppl II, 77 (abstract).

10 Davies M J, Moore B P, Braimbridge M V. The floppy mitral valve-study of incidence, pathology and complications in surgery, necropsy and forensic material. Br Heart J 1978; 40: 468-81.

20 Pocock W A, Barlow J B. Etiology and electrocardiographic features of the billowing posterior mitral leaflet syndrome: analysis of a further 130 patients with a late systolic murmur or non-ejection systolic click. Am J Med 1971; 51 : 731-9.

21 Brown O R, Demots H, Kloster J E, Roberts A, Menashe V D, Beals R K. Aortic root dilatation and mitral valve prolapse in Marfan's syndrome. Circulation 1975; 52: 651-7.

22 Brandt K D, Sumner R D, Ryan T J, Cohen A S. Herniation of mitral valve leaflets in the Ehlers-Danlos syndrome. Am J Cardiol 1975; 36: 524-8.

${ }^{23}$ Cabeen W R, Reza M J, Kovick R B, Stern M S. Mitral valve prolapse and conduction defects in Ehlers-Danlos syndrome. Arch Intern Med 1977; 137: 1227-31.

24 Woods S J, Thomas J, Braimbridge M V. Mitral valve disease and open heart surgery in osteogenesis imperfecta tarda. Br Heart J 1973; 35: 103-6.

${ }_{25}$ Grahame R, Beighton P. The physical properties of the skin in the Ehlers-Danlos syndrome. Ann Rheum Dis 1969 ; 28 : 246-51.

26 Harvey W, Grahame R, Smith R, Francis O. Physical properties of the skin in osteogenesis imperfecta (unpublished"data).

27 Lapière $\mathbf{C ~ M}$, Nusgens B. Collagen pathology at molecular level. In: Ramachandran G N, Reddi A H, eds. Biochemistry of Collagen. New York, London: Plenum Press, 1976: 377-448.

28 Bonella D, Parker D J, Davies M J. Accumulation of procollagen in human floppy mitral valves. Lancet 1980 ; i: $880-1$. 